\title{
"Mind the scenery!" Landscape depiction and the travel intentions of Game of Thrones fans: some insights for DMOs
}

Ariel Mitev Screen tourism is becoming increasingly popular.

Corvinus University

of Budapest, Hungary

E-mail:

ariel.mitev@uni-corvinus.hu

Anna Irimiás

University of Trento, Italy

Kodolányi University

of Applied Sciences, Hungary

E-mail:

annarita.irimias@unitn.it

Gábor Michalkó

Hungarian Academy

of Sciences,

Geographical Institute,

Hungary

Corvinus University

of Budapest, Hungary

E-mail: michalko@mail.iif.hu

\section{Mariangela Franch}

Universtiy of Trento, Italy

E-mail:

mariangela.franch@unitn.it

\section{Keywords:}

screen tourism,

landscape,

place attachment,

travel intention,

PLS-SEM
Successful feature films and television series can form, enhance or alter place image, and put filming locations on tourists' mental maps. Very little is known, however, about how the resonance of landscape depiction and place attachment may affect the gathering of information about different filming locations and, consequently, consumers' travel intentions. This study seeks to identify a nexus between landscape depiction and travel intention through an exploration of the fantasy television series Game of Thrones (GoT). The structured questionnaire survey carried out with 314 GoT fans reveals that different dimensions have had a scale-effect on travel intentions. Partial least squares structural equation modelling (PLS-SEM) - considered the most appropriate for this exploratory study - was applied for the data analysis. The results indicate that landscape depiction has a positive effect on place attachment, information gathering and travel intentions, thus providing destination management organisations (DMOs) with opportunities to interact with potential tourists to promote filming locations. 
"Mind the scenery!" Landscape depiction and the travel intentions of Game of Thrones fans: some in-sights for DMOs

"We're in the business of creating addicts." HBO CEO Richard Plepler

\section{Introduction}

Content producers and distributors like HBO are determined to capture people's imaginations and make them loyal consumers by broadcasting high quality entertainment using new media technologies and screens (Scharl et al. 2016). Game of Thrones (GoT) is an expensively produced and extremely popular HBO series based on the epic fantasy cycle $A$ Song of Ice and Fire by George R. R. Martin. The series premiered in 2011 and its seventh season, which started in August 2017, was watched by 16.1 million $\mathrm{HBO}$ subscribers and about 21 million pirate viewers (www.independent.co.uk). The storyline follows two rival families waging war on each other in a twisted game for control of the Seven Kingdoms and its medievalstyle headquarters, the city of Kings' Landing. Tangled family weave through the struggle rich in intrigue, violence, sex and fights for political and royal power (Stanton 2015). The latest season and its extensive media coverage have further broadened the series' already highly active international fan base (Business Insider 2017). GoT has been popular with critics and viewers, and received more than 30 Emmy awards. The commitment of the series' fans is evidenced by their enthusiastic following of each episode, which they actively discuss and tweet about on social media, their creation of virtual communities, and by their producing and consuming (prosuming) of Go'T news and stories (Beveridge-Shan 2016, Scharl et al. 2016).

All 70 GoT episodes have been distinguished by their expert characterisation and careful attention to detail in the presentation of the atmosphere in which landscape plays a key role. The complex relationships between the more than 30 vividly drawn, memorable, leading characters and the intricate plotlines keep audiences alert (Beveridge-Shan 2016). Historical and geographical notions, such as references to England's $15^{\text {th }}$ century War of the Roses between the Houses of Lancaster and York, are embedded in both the novels and the series, endowing plotlines with some realism (Larrington 2016). The complex construction and communication of spatial knowledge of Westeros, the Lands of Always Winter, Iron Island, Bay of Dragons, etc. is reinforced by the 3D maps in the opening sequences of the show (Marshall 2015). GoT frequently uses long shots of cultural and natural landscapes and landscapes are rarely shown for their beauty alone: as an in-depth sentiment analysis has shown, their portrayal - often imbued with the emotions elicited by the film's characters - almost always serves a dramatic purpose (Scharl et al. 2016). Host cities are credited at the end of each episode, allowing keen-viewers to identify even digitally modified scenery as a particular geographical filming location. GoT has been filmed mainly in Europe, in six different countries (see Table 1) and in 42 loca-

Regional Statistics, Vol. 7. No. 2. 2017: 58-74; DOI: 10.15196/RS07201 
tions, some of which are UNESCO World Heritage sites and thus bear strong cultural and heritage place identity (King-Halpenny 2014).

Key Game of Thrones filming locations

Table 1

\begin{tabular}{|c|c|c|}
\hline \multicolumn{3}{|c|}{ Key Game of Thrones filming locations } \\
\hline Country of filming & $\begin{array}{l}\text { UNESCO World Heritage Site } \\
\text { (fantasy location) }\end{array}$ & Game of Thrones fantasy location \\
\hline Croatia & $\begin{array}{l}\text { Old City of Dubrovnik (King's Land- } \\
\text { ing) } \\
\text { Diocletian's Palace, Split (Meereen) } \\
\text { Historic City of Trogir (Qarth) } \\
\text { The Cathedral of Saint James of } \\
\text { Sibenik (Braavos) }\end{array}$ & $\begin{array}{l}\text { King's Landing, King's Landing Pal- } \\
\text { ace Gardens, Braavos, Red Keep, } \\
\text { House of the Undying, Meereen, } \\
\text { Qarth }\end{array}$ \\
\hline Iceland & $\begin{array}{l}\text { Thingvellir National Park (The Ey- } \\
\text { rie) }\end{array}$ & $\begin{array}{l}\text { Arrowhead Mountain, Beyond the } \\
\text { Wall, Jon and Ygritte's love cave, The } \\
\text { Eyrie }\end{array}$ \\
\hline $\begin{array}{l}\text { Northern Ireland, } \\
\text { United Kingdom }\end{array}$ & - & $\begin{array}{l}\text { The Wall, Castle Black, Winterfell, } \\
\text { Iron Islands, King's Road, Dragon- } \\
\text { stone, The Crownlands, Riverrun, } \\
\text { The Stormlands }\end{array}$ \\
\hline $\begin{array}{l}\text { Scotland, United } \\
\text { Kingdom }\end{array}$ & & Winterfell, Slavers' Bay \\
\hline Spain & $\begin{array}{l}\text { Alcazar of Seville (Dorne, } \\
\text { Sunspear) } \\
\text { Historic Center of Cordoba } \\
\text { (Volantis) }\end{array}$ & $\begin{array}{l}\text { Tower of Joy, Dothraki Sea, Dragon- } \\
\text { stone, Dorne, High Garden, Meeren, } \\
\text { Braavos, Volantis }\end{array}$ \\
\hline Malta & City of Valletta (King's Landing) & $\begin{array}{l}\text { Red Keep, King's Landing Gate, } \\
\text { King's Landing, Pentos }\end{array}$ \\
\hline Morocco & The city of Essaouira (Astapor) & Yunkai, Astapor, Pentos \\
\hline
\end{tabular}

Source: Own elaboration; the list of locations is not exhaustive.

This study increases our knowledge of how the portrayal of natural and urban landscapes has influenced Go'T viewers' information gathering on various locations, and subsequently their travel intentions vis a vis filming locations.

\section{Landscape depiction and trips to fantasy worlds}

Film and screen experiences are undeniably powerful image creators that can give symbolic meaning to cultural products and experiences (Kim 2010, Lundberg et al. 2017, Urry 1994). According to Chris Rojek (1997), tourists have concrete ideas of particular places because they have seen them in pictures, films and television programmes or have read books or magazines in which the places were featured. Media-generated perceived familiarity with places gives meaning to locations (Bódi 2008). This is particularly true for fantasy movies linked to distinct landscapes and

Regional Statistics, Vol. 7. No. 2. 2017: 58-74; DOI: 10.15196/RS07201 
"Mind the scenery!" Landscape depiction and the travel intentions of Game of Thrones fans: some in-sights for DMOs

locations, such as the Lord of the Rings movies (Beeton 2016) or the numerous Star Wars movie series (Escher et al. 2008). It has been widely acknowledged that through storytelling and landscape depiction - films and television series can influence viewers' perceptions of places and increase visitor numbers to filming locations (Busby-Klug 2001, Busby-Haines 2013, Im-Chon 2008, Iwashita 2008, O'Connor et al. 2008, Reijnders 2010a).

Recently, screen tourism, i.e. visits to the filming locations of television series/films, has received considerable attention from both academics and the tourism industry (Beeton 2016, Connell 2012). In fact, the phenomenon was also widely studied in the 1990s (Tooke-Baker 1996, Riley-Van Doren 1992). Our assumption is therefore that the importance that viewers attribute to landscape depiction raises their interest in, and attachment to, the screened landscape of a particular destination. Based on the previous literature, the following hypotheses can be formulated:

H1: Resonance of landscape depiction strengthens place attachment.

H2: Resonance of landscape depiction affects viewers' information gathering about locations.

Busby and Haines (2013) have claimed that the British television comedy drama Doc Martin was one of the primary motivations leading visitors to go to the depicted locality, the fishing village of Port Isaac in Cornwall, in 2011. Screen tourism is not just a Western phenomenon. Internationally distributed Turkish soap operas have attracted record-breaking audiences and significantly raised in-bound tourism to Turkey (Balli et al. 2013). The endorsement of leading actors, such as Kivanç Tatlituğ, played a key role in branding Turkey and creating place attachment among fans and tourists (Busby et al. 2013). Regular watching of television dramas creates emotional bonds not only with the characters but also with the featured background and cultural landscape (Irimiás 2015). The stronger the viewer's emotional involvement with a storyline, and the more meaningful to them the landscape, the more likely they will be to travel to locations, as the popularity of South Korean television series with Japanese tourists has shown (Kim 2012). It can therefore be assumed that visual landscape narratives are likely to increase visitor numbers to filming locations:

H3: Resonance of landscape depiction has a positive effect on travel intentions.

Locations familiar to drama viewers, such as the privately owned heritage location of Highclere castle in the British series Downton Abbey, are associated with engaging storylines and stimulate fans to gather information on, and even visit, the site itself (Lundberg et al. 2017). Reijnders (2010b) argued that information gathering on James Bond filming sites, such as locating the secret door leading to the MI6 headquarters on Westminster Bridge in London, is essential for fans to link physical places to those in a fantasy world. Based on this evidence, we have formulated the following hypotheses:

Regional Statistics, Vol. 7. No. 2. 2017: 58-74; DOI: 10.15196/RS07201 
H4: Place attachment has a positive effect on information gathering about locations.

H5: Place attachment has a positive effect on travel intentions.

H6: Information gathering about locations has a positive effect on travel intentions.

Iconic places are not the only pull factors for film tourists (Macionis 2004). Even intentionally undistinctive streets and built environments in sci-fi television series, such as Smallville and $X$-files set in Vancouver, are attracting viewers. Apparently characterless 'non-places' (Augè 1995) can be extremely rich in symbols and signs for sci-fi fans and weave a web of urban mystery that only those "in the know" can decode (Brooker 2007). Fans' geographical reading of a symbolic on-location Vancouver thus creates a meaningful experience through place attachment and information gathering about locations.

\section{DMO initiatives to leverage screen tourism}

Various tourism-marketing initiatives implemented by destinations to increase the potential of films and television series to attract film tourists to destinations have been described in the literature (Beeton 2016, Buchmann et al. 2010, Hahm-Wand 2011, Iwashita 2008, Lin-Huang 2008). Iconic films are often identified with their geographical locations. Although cultural products such as films are not created with the intention of attracting tourists to their locations, functional site placement (similar to product placement) enhances the attractiveness of locations and forms, reinforces or alters destination image (Croy 2010, O'Connor 2011, Papp-Váry 2015). The unprecedented popularity by the screen sets different challenges to featured locations and especially to historic cities and urban settlements (Puczkó-Rátz 2003). There is evidence that Forks in the US and the Italian city of Volterra, depicted in the Twilight novels and movies, have become popular destinations among vampire story fans (Larson et al. 2013): these fans represent a new tourist segment for the destinations, and the DMOs have had to respond to the challenge of meeting their needs.

DMOs can implement several strategies to leverage on the popularity of films to raise tourist awareness and reinforce brand building (Hudson-Ritchie 2006, VoloIrimiás 2016). The producers of the Lord of the Rings saga (Buchmann 2010, Jones-Smith 2005) and of The Hobbit (Li et al. 2017, Lundberg et al. 2017) worked with New Zealand's DMOs in a joint marketing campaign to relabel and brand the country as " $100 \%$ Middle-Earth" to explore New Zealand (Lundberget al. 2017).

Hudson and Ritchie (2006) elaborated a detailed model on pre- and post-release marketing initiatives that destinations could exploit. The focus is on film-specific factors and the film locations need to be identifiable and accessible and have an emotional resonance and a physical icon that fans can identify. DMOs can partici-

Regional Statistics, Vol. 7. No. 2. 2017: 58-74; DOI: 10.15196/RS07201 
"Mind the scenery!" Landscape depiction and the travel intentions of Game of Thrones fans: some in-sights for DMOs

pate in the pre- and post-release periods, creating marketing initiatives that target film-tourists. As Frost (2010) has shown, investing in a promotional campaign constructed around a film, as was done by Tourism Australia in 2008 to leverage on the film Australia, while not uncommon, is potentially risky, because no film's success is guaranteed. The new 'Victoria's Island' Trail was launched in 2017, long before the release of the film Victoria and Abdul, to promote Osborne, the seaside residence of the Queen. The Isle of Wight DMO invested more than $£ 200,000$ in the campaign, on thematic tours and movie maps, and interactive guides to the island's heritage sites (visitwightpro.com).

Other marketing initiatives involve built attractions such as theme parks or film related museums/exhibitions. In South Korea, a highly successful theme park reproduces the royal kitchen and hospital of the cooking maid Daejanggeum, and received more than 180,000 visitors in the two years after its opening, it has been proposed that this popularity is due to the fact that viewers are responding to the emotional appeal of the screen stories linked to the place (Kim 2012, Kim et al. 2008). Specific products and services need to be developed to meet screen tourists' needs: when on location, fans want to imitate film characters and re-enact their favourite scenes, as both James Bond and South Korean drama fans have demonstrated (Reijnders 2010b, Kim 2010). Experiential events celebrating the Lord of the Rings and The Hobbit, or the fan event inspired by the television series Supernatural filmed in Vancouver, are created to facilitate place recognition and to allow fans to have memorable film-based on-location experiences (Lundberg et al. 2017; Hudson-Ritchie 2006, Connell 2012). Previous studies have shown that DMOs implement a variety of marketing strategies based on film or television series releases (Volo-Irimiás 2016). No in-depth study of interactions with potential tourists investigating viewers' place attachment, information gathering and travel intention has yet been done, however. Game of Thrones is deemed particularly interesting in the study of landscape depiction and travel intentions. The series are mainly set in Europe and some film locations are within UNESCO World Heritage sites (see Table 1); the urban and natural landscape is closely interwoven into the fantasy storyline. Memorable characters and violent and adult content influence the destination image of film locations. The interrelations of our hypotheses constitute the theoretical framework of this study, summarised in Figure 1.

Regional Statistics, Vol. 7. No. 2. 2017: 58-74; DOI: 10.15196/RS07201 


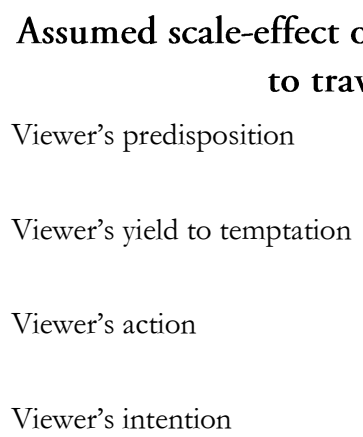

Figure 1 to travel to GoT locations

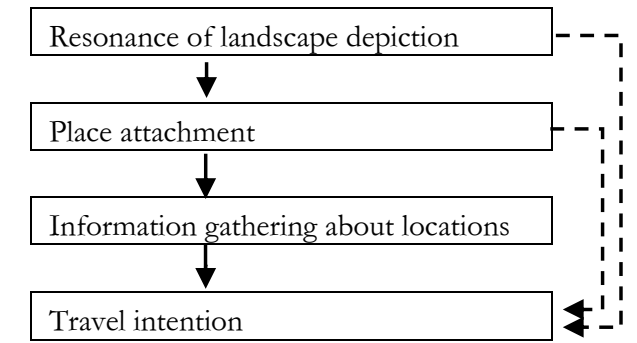

Note: The direct arrows indicate direct effects; the dotted arrows denote indirect effects.

Source: Own elaboration.

The suggestive, iconic GoT filming locations quickly became fan pilgrimage sites, boosting tourism to destinations that have acquired new layers of meaning through the storylines (Beeton 2016). GoT-tourists have flocked to the Adriatic Sea, and above all to Dubrovnik (Croatia), the GoT Kings' Landing. According to Tkalec et al. (2017), tourist arrivals increased by 37.9\% between 2011 and 2015 and about 1 million tickets were sold to the city's walls in 2016. Similarly, Gozo (Malta) and Belfast (Northern Ireland) saw a dramatic increase in international tourism arrivals in the first seven months of 2017. Future GoT seasons are very likely to increase audience share, thus stimulating interest in filming locations among different consumer segments, and challenging DMOs' ability to communicate with GoTtourists.

\section{Methodology}

The purpose of this paper is to investigate the nexus between landscape depiction, place attachment and travel intentions. Our research focused on the GoT HBO television series, and investigated the landscape depiction of the series' filming locations. Table 1 includes the most important GoT filming locations.

\section{Research instrument and data collection}

The research instrument used was a structured questionnaire survey, the items of which were based on the literature on film-induced tourism, within which we identified those items that could be used or modified to develop appropriate scales. The pilot survey and main data collection were done in Budapest, Hungary - the former in August 2016, the latter between September and November 2016.

Regional Statistics, Vol. 7. No. 2. 2017: 58-74; DOI: 10.15196/RS07201 
"Mind the scenery!" Landscape depiction and the travel intentions of Game of Thrones fans: some in-sights for DMOs

\section{Sample}

Hungarian GoT fans were contacted through a snowball sample of students from the Corvinus University of Budapest. The chosen respondents had to have watched at least three of the six GoT seasons. The convenience sample consisted of 314 Hungarian respondents aged 18 to 35 years who were willing to fill out the questionnaire. $84.1 \%$ of the survey participants had watched all six GoT seasons, and $19.7 \%$ had already visited at least one GoT filming location, while most $(80.3 \%)$ had only indirect experience of the filming locations.

\section{Data analysis}

Variance-based PLS-SEM was applied to test the model. Data analysis was conducted with ADANCO software (Dijkstra-Henseler 2015). The exploratory nature of the research justified the use of PLS-SEM (see e.g. Hair et al. 2012).

\section{Measures and the quality criteria of the measurement model}

As there are no internationally pre-tested scales, newly developed scales were used in this study (see Appendix). Each item was measured on a seven-point Likert scale, ranked from $1=$ strongly disagree to $7=$ strongly agree. Landscape resonance is a self-developed scale with two statements intended to measure how important natural and urban landscape depiction is to GoT viewers. The scale validity is good (Cronbach $\alpha=0.86$ ). The place attachment scale was also developed for this study, three statements measure the strength of viewers' attraction to the depicted landscapes. The scale validity is good (Cronbach $\alpha=0.77$ ). An information gathering about locations scale, too, was developed for the study, it includes three statements to measure how actively viewers search visual and textual information about GoT locations. The scale validity is good (Cronbach $\alpha=0.77$ ). To measure travel intention, a three-item scale by Shani et al. (2009) was adopted. The scale validity is good (Cronbach $\alpha=0.79$ ).

The three self-developed scales and the adopted scale required the use of PLSSEM.

It is possible to test convergent validity with standardized factor loadings more than 0.5 ( 0.4 in exploratory research), but, ideally, 0.7 should be reached (Hair et al. 2012). The Appendix indicates Dijkstra-Henseler's $\varrho A$ values - the index of internal consistency reliability measure of constructs, which is well above the favourable 0.7 value in each case (Dijkstra-Henseler 2015). The index applied to measure convergent validity is average variance extracted (AVE), where values should be more than 0.5 in each construct (Hair et al. 2006). AVE can be found on the diagonal of Table 2. The data meet the required criteria.

Regional Statistics, Vol. 7. No. 2. 2017: 58-74; DOI: 10.15196/RS07201 
Discriminant validity was measured by Fornell and Larcker's test (1981), where, in all cases, the AVE measure is larger than the squared latent variable correlations of all the other constructs. As Table 1 demonstrates, this requirement has been met.

Table 2

Discriminant validity: Fornell-Larcker criterion

\begin{tabular}{|c|c|c|c|c|}
\hline Construct & $\begin{array}{c}\text { Travel } \\
\text { intention }\end{array}$ & $\begin{array}{c}\text { Information } \\
\text { gathering } \\
\text { about locations }\end{array}$ & $\begin{array}{c}\text { Resonance } \\
\text { of landscape } \\
\text { depiction }\end{array}$ & $\begin{array}{c}\text { Place } \\
\text { attachment }\end{array}$ \\
\hline Travel intention & 0.7041 & & & \\
\hline Information gathering about locations & 0.3032 & 0.6823 & & \\
\hline Resonance of landscape depiction & 0.0985 & 0.0989 & 0.8806 & \\
\hline Place attachment & 0.2513 & 0.3096 & 0.2096 & 0.6901 \\
\hline
\end{tabular}

Note: AVE values can be found on the diagonal; values under the diagonal are the squared latent variable correlations of each construct.

Source: Own calculation.

Discriminant validity was measured by the heterotrait-monotrait ratio of correlations (HTMT) ${ }^{1}$, where each pair of constructs must be significantly lower than 1; this criterion is met in our study (see Table 3).

Table 3

\begin{tabular}{|c|c|c|c|c|}
\hline Construct & $\begin{array}{c}\text { Travel } \\
\text { intention }\end{array}$ & $\begin{array}{c}\text { Information } \\
\text { gathering } \\
\text { about locations }\end{array}$ & $\begin{array}{c}\text { Resonance } \\
\text { of landscape } \\
\text { depiction }\end{array}$ & $\begin{array}{c}\text { Place } \\
\text { attachment }\end{array}$ \\
\hline \multicolumn{5}{|l|}{ Travel intention } \\
\hline Information gathering about locations & 0.7041 & & & \\
\hline Resonance of landscape depiction & 0.3789 & 0.3833 & & \\
\hline Place attachment & 0.6343 & 0.7107 & 0.5539 & \\
\hline
\end{tabular}

Source: Own calculation.

In sum, enough statistical evidence was found to verify the existence of the four constructs, and to verify that the measured variables are appropriate indicators of the related factors and that the constructs are different.

\footnotetext{
${ }^{1}$ The HTMT of the correlations, which is the average of the heterotrait-heteromethod correlations (i.e. the correlations of indicators across constructs measuring different phenomena), is relative to the average of the monotrait-heteromethod correlations (i.e. the correlations of indicators within the same construct).
}

Regional Statistics, Vol. 7. No. 2. 2017: 58-74; DOI: 10.15196/RS07201 
"Mind the scenery!" Landscape depiction and the travel intentions of Game of Thrones fans: some in-sights for DMOs

\section{Structural model and results}

Only one model fit criterion, the standardized root mean square residual (SRMR) is applied in PLS modelling, its cut-off value is 0.08 (Hu-Bentler 1999). The model delineated in this study has an appropriate model fit, because SRMR $=0.072$. The results (see Table 4 and Figure 2) demonstrate that not every hypothesis was accepted.

Table 4

\begin{tabular}{|c|c|c|c|}
\hline \multicolumn{4}{|c|}{ Direct effects in the model } \\
\hline & $\beta$ & $t$-value & $p$-value \\
\hline Resonance of landscape depiction $\rightarrow$ Place attachment $(\mathrm{H} 1+)$ & 0.4579 & 9.8086 & 0.0000 \\
\hline $\begin{array}{l}\text { Resonance of landscape depiction } \rightarrow \text { Information gathering } \\
\text { about locations }\left(\mathrm{H}^{2+}+\right)\end{array}$ & 0.0755 & 1.4994 & 0.1341 \\
\hline Resonance of landscape depiction $\rightarrow$ Travel intention $(\mathrm{H} 3+$ ) & 0.0775 & 1.4758 & 0.1403 \\
\hline $\begin{array}{l}\text { Place attachment } \rightarrow \text { Information gathering about locations } \\
(\mathrm{H} 4+)\end{array}$ & 0.5218 & 11.9429 & 0.0000 \\
\hline Place attachment $\rightarrow$ Travel intention $(\mathrm{H} 5+)$ & 0.2505 & 5.1369 & 0.0000 \\
\hline Information gathering about locations $\rightarrow$ Travel intention $(\mathrm{H} 6+)$ & 0.3869 & 6.9376 & 0.0000 \\
\hline
\end{tabular}

Note: Unverified hypotheses are written in italics. + indicates positive effect.

Source: Own calculation using ADANCO software.

Resonance of landscape depiction has a positive effect on place attachment ( $\beta=0.46$ ), which means that the more important natural and urban landscapes are for viewers, the stronger place attachment becomes, leading viewers to be more attracted to locations (the $\mathrm{H} 1$ hypothesis is accepted). It might seem surprising that landscape resonance does not have a positive effect on either information gathering or travel intentions (no significant correlation, the $\mathrm{H} 2$ and $\mathrm{H} 3$ hypotheses are rejected), although indirect effects are significant in both cases.

Resonance of landscape indirectly affects information gathering about locations through place attachment $(\beta=0.24 ; t$-value $=7.74 ; p$-value $=0.000)$, and - in a similarly indirect way (through place attachment and information gathering about locations $)$ - has a positive effect on travel intentions $(\beta=0.24 ; t$-value $=6.85$; $p$-value $=0.000)$.

This means that the predisposition of viewers to find resonance in the landscapes depicted in GoT is just the first step in the formulation of travel intentions. Our research reveals a multilevel scale in which each step can potentially be managed by the destination or the supply side, to influence travel intentions. Landscape depiction does not directly determine travel intentions but does have an indirect impact on them.

Place attachment has a positive effect on information gathering about locations ( $\beta=0.52)$ : the more attractive and meaningful a film location is, the stronger the

Regional Statistics, Vol. 7. No. 2. 2017: 58-74; DOI: 10.15196/RS07201 
interest in information gathering about that location becomes (the H4 hypothesis is accepted). Place attachment is mainly determined by the visual narrative of GoT.

Place attachment affects travel intentions positively both directly $(\beta=0.25$; the $\mathrm{H} 5$ hypothesis is accepted) and indirectly through information gathering about locations $(\beta=0.20 ; t$-value $=6.23 ; p$-value $=0.000)$. This means that the more attractive a film location is, the stronger travel intentions become, which means that viewers' intentions to visit a location can be strengthened by simply increasing that location's on-screen attractiveness. Furthermore, strong place attachment motivates viewers to act and increases information search activity, leading to stronger commitment.

Figure 2

\section{Structural model and results}

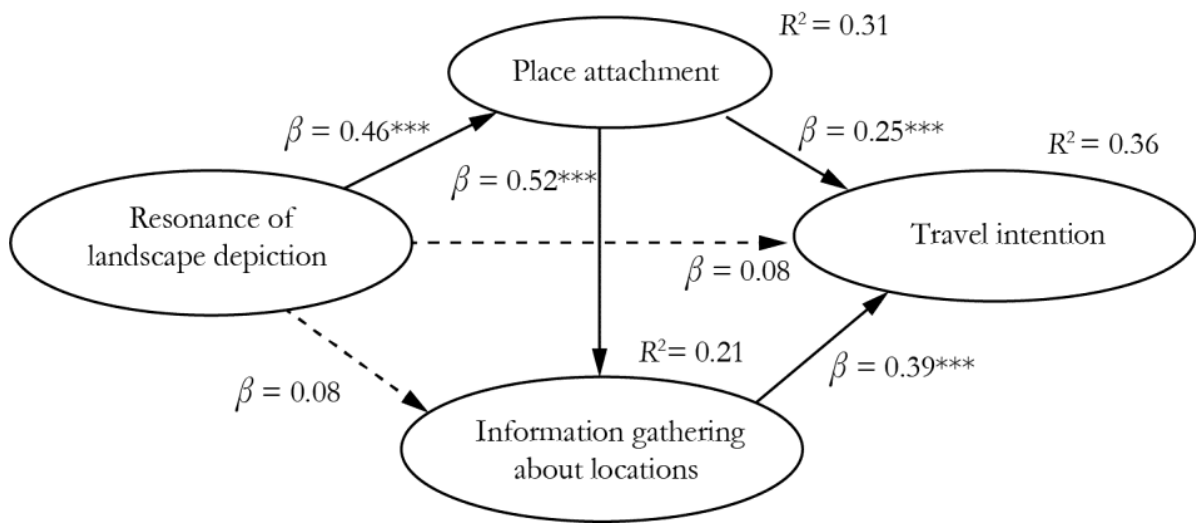

Note: Every path coefficient is standardized (*** $p<0.001)$. The dotted lines represent the rejected hypotheses. Source: Own elaboration.

Information gathering about locations has a positive effect on travel intentions $(\beta=0.39)$. This means that information gathering leads to greater commitment: knowing more about a location inspires viewers to want to discover and experience that place themselves (the H6 hypothesis is accepted). Information gathering is a cognitive effort involving the examination of visual material about locations, comparing fictional images and photos, and discovering surprising and/or engaging information about destinations (see Table 5). From the marketing communication point of view, intervention at this point can be crucial to convincing viewers to actually visit a filming location. The quality of the information that viewers find, of course, partly depends on their own activities in selecting and distinguishing visual and textual content. However, if destinations can provide easy access to information, this will clearly be to their own advantage. The link between the real and fantasy world must be made evident in order to involve viewers in the discovery of a location.

Regional Statistics, Vol. 7. No. 2. 2017: 58-74; DOI: 10.15196/RS07201 
"Mind the scenery!" Landscape depiction and the travel intentions of Game of Thrones fans: some in-sights for DMOs

Table 5

Direct and indirect effects in the model

\begin{tabular}{|c|c|c|c|c|}
\hline \multirow[t]{2}{*}{ Effect } & $\begin{array}{l}\text { Direct } \\
\text { effect }\end{array}$ & $\begin{array}{c}\text { Indirect } \\
\text { effect }\end{array}$ & $\begin{array}{l}\text { Total } \\
\text { effect }\end{array}$ & \multirow{2}{*}{$\begin{array}{c}\text { Cohen's } \\
f^{2}\end{array}$} \\
\hline & \multicolumn{3}{|c|}{$\beta$} & \\
\hline $\begin{array}{l}\text { Information gathering about locations } \rightarrow \text { Travel inten- } \\
\text { tion }\end{array}$ & 0.3869 & & 0.3869 & 0.1612 \\
\hline Resonance of landscape depiction $\rightarrow$ Travel intention & 0.0775 & 0.2364 & 0.3139 & 0.0074 \\
\hline $\begin{array}{l}\text { Resonance of landscape depiction } \rightarrow \text { Information } \\
\text { gathering about locations }\end{array}$ & 0.0755 & 0.2389 & 0.3144 & 0.0066 \\
\hline Resonance of landscape depiction $\rightarrow$ Place attachment & 0.4579 & & 0.4579 & 0.2652 \\
\hline Place attachment $\rightarrow$ Travel intention & 0.2505 & 0.2019 & 0.4524 & 0.0593 \\
\hline $\begin{array}{l}\text { Place attachment } \rightarrow \text { Information gathering about loca- } \\
\text { tions }\end{array}$ & 0.5218 & & 0.5218 & 0.3137 \\
\hline
\end{tabular}

Source: Own calculation using ADANCO software.

\section{Conclusions}

This research has several limitations, one of which is the limited sample size of Hungarian GoT fans. The constructs, moreover, were based on the perceptions of GoT viewers. Some conclusive marks have nevertheless emerged from our findings. The attraction of GoT filming locations acts like a magnet, drawing viewers to film locations in order to experience them personally. The point at which viewers' interest is first aroused, and they begin to gather information about locations, and wish to discover more about them, is key for tourism marketers. DMOs and marketers should implement several strategies to interact with potential tourists and to promote film locations as destinations. Destinations can leverage landscape depiction by highlighting their connections with GoT through short YouTube videos and promotional videos shared on interactive social media platforms and released simultaneously with GoT premieres. Information gathering about film locations requires cognitive efforts and may not be embarked upon immediately after watching a GoT episode. DMOs should therefore provide all the relevant information about film locations three to five weeks after the start of a new GoT season. DMOs should focus on viewers' travel intentions when the previous three steps on the scale-effect - resonance of landscape depiction, place attachment and information gathering - have been taken into consideration by marketers. The GoT film locations are extremely diverse: cold, inhospitable places, filmed in Iceland and the forests and moorlands of Northern Ireland; deserts, filmed in Spain, and stunning medieval cities in Croatia. Communication about the destination is always key to successful marketing. While Dubrovnik has been swamped by mass tourism and needs to implement strict rules to manage the site and the access to the medieval city cen-

Regional Statistics, Vol. 7. No. 2. 2017: 58-74; DOI: 10.15196/RS07201 
tre, Belfast and the locations in the Northern Irish countryside should be more proactive in attracting media attention, organising events and festivals and involving celebrities to promote GoT film locations. An understanding of the scale-effect between landscape depiction, place attachment and information gathering, which determines travel intentions, is useful for DMOs who wish to structure promotional strategies and interact with potential tourists.

\section{Acknowledgements}

This study is part of a three-year (2016-2019) research programme, 'The role of cultural industries in innovative territorial development: A complex geographical analysis' supported by the Bolyai János Scholarship of the Hungarian Academy of Sciences, which has been awarded to the second author. The authors wish to thank Bettina Padula and Bernadett Zsiros from the Corvinus University of Budapest for their kind assistance in data gathering.

\section{REFERENCES}

AUGÈ, M. (1995): Non-places. Introduction to an anthropology of supermodernity Versus, London. https://doi.org/10.1177/030981689606000111

BALli, F.-BALli, H. O.-CEBECI, K. (2013): Impacts of exported Turkish soap operas and visa-free entry on inbound tourism to Turkey. Tourism Management 37: 186192. https://doi.org/10.1016/j.tourman.2013.01.013

Beeton, S. (2016): Film-induced Tourism. $2^{\text {nd }}$ Edition Channel View Publications, Cleveland.

Beveridge, A.-Shan, J. (2016): Network of Thrones Math Horizons 23 (4): 18-22. https://doi.org/0.4169/mathhorizons.23.4.18

BóDI, J. (2008): A turistatekintet mögött Debreceni Disputa 6 (5): 4-9.

BROOKER, W. (2007): Everywhere and nowhere: Vancouver, fan pilgrimage and the urban imaginary International Journal of Cultural Studies 10 (4): 423-444. https://doi.org/10.1177/1367877907083078

Buchmann, A. (2010): Planning and development in film tourism: insights into the experience of Lord of the Rings film guides Tourism and Hospitality Planning and Development 7 (1): 77-84. https://doi.org/10.1080/14790530903522648

Buchmann, A.-Moore, K.-Fisher, D. (2010): Experiencing film tourism. Authenticity and Fellowship Annals of Tourism Research 37 (1): 229-248. https://doi.org/10.1016/j.annals.2009.09.005

BusBY, G.-ERGUL, M.-ENG, J. (2013): Film tourism and the lead actor: an exploratory study on the influence on destination image and branding Anatolia 24 (3): 395-404. https://doi.org/10.1080/13032917.2013.783874

Busby, G.-HAINES, C. (2013): Doc Martin and film tourism. The creation of destination image Tourism 61 (2): 105-120.

BusBY, G.-KLUG, J. (2001): Movie-induced tourism: the challenge of measurement and other issues Journal of Vacation Marketing 7 (4): 316-332. https://doi.org/10.1177/135676670100700403

Regional Statistics, Vol. 7. No. 2. 2017: 58-74; DOI: 10.15196/RS07201 
"Mind the scenery!" Landscape depiction and the travel intentions of Game of Thrones fans: some in-sights for DMOs

Connell, J. (2012): Film tourism - Evolution, progress and prospects Tourism Management 33: 1007-1029. https://doi.org/10.1016/j.tourman.2012.02.008

CROY, W.G. (2010): Planning for film tourism: active destination image management Tourism and Hospitality Planning and Development 7 (1): 21-30. https://doi.org/10.1080/14790530903522598

Dijkstra, T. K.-Henseler, J. (2015): Consistent Partial Least Squares Path Modeling MIS Quarterly 39 (2): 297-316.

EsCHER, A.-RIEMPP, E.-WÜsT, M. (2008): In the footsteps of Jedi knights and sea pirates Hollywood movies and tourism in Tunisia Geographische Rundschau International Edition 4 (3): 46-52.

FORNELL, C.-LARCKER, D. F. (1981): Evaluating structural equation models with unobservable variables and measurement error Journal of Marketing Research 18 (1): 39_ 50.

Frost, W. (2010): Life changing experiences. Film and tourists in the Australian outback Annals of Tourism Research 37 (3): 707-726. https://doi.org/10.1016/ j.annals.2010.01.001

HAHM, J.-WAND, Y. (2011): Film-induced tourism as a vehicle for destination marketing: is it worth the efforts? Journal of Travel and Tourism Marketing 28 (2): 165-179. https://doi.org/10.1080/10548408.2011.546209

HAiR, J. F.-SARSTEDT, M.-RingLE, C. M.-MENA, J. A. (2012): An assessment of the use of partial least squares structural equation modeling in marketing research Journal of the Academy of Marketing Science 40 (3): 414-433. https:/ / doi.org/10.1007/ s11747-011-0261-6

Hu, L.T.-BENTLER, P. M. (1999): Cut-off criteria for fit indexes in covariance structure analysis: conventional criteria versus new alternatives Structural Equation Modeling 6 (1): 1-55. https://doi.org/10.1080/10705519909540118

Hudson, S.-Ritchie, B. (2006): Promoting destinations via film tourism: an empirical identification of supporting marketing initiatives Journal of Travel Research 44 (2): 387-396. https://doi.org/10.1177/0047287506286720

IM, H.H.-CHON, K. (2008): An exploratory study of movie-induced tourism: a case of the movie The Sound of Music and its locations in Salzburg, Austria Journal of Travel and Tourism Marketing 24 (2-3): 229-238. https://doi.org/10.1080/ 10548400802092866

IrImiÁs, A. (2015): Filmturizmus. A filmek és televíziós sorozatok turisztikai szerepének és hatásainak geográfiai vizsgálata Akadémiai Kiadó, Budapest.

IWASHITA, C. (2008): Roles of films and television dramas in international tourism: the case of Japanese tourists to the UK Journal of Travel and Tourism Marketing 24 (23): 139-151. https://doi.org/10.1080/10548400802092635

Jones, D.-SMith, K. (2005): Middle-earth New Zealand: authenticity and location in the making of the Lord of the Rings Journal of Management Studies 42 (5): 923945. https://doi.org/10.1111/j.1467-6486.2005.00527.x

KIM, S. (2010): Extraordinary experiences: re-enacting and photographing at screen tourism locations Tourism and Hospitality Planning and Development 7 (1): 59-75. https://doi.org/10.1080/14790530903522630

Regional Statistics, Vol. 7. No. 2. 2017: 58-74; DOI: 10.15196/RS07201 
KIM, S. (2012): Audience involvement and film tourism experiences: emotional places, emotional experiences. Tourism Management 33 (2): 387-396. https://doi.org/10.1016/j.tourman.2011.04.008

KIM, S.S.-AgrusA, J.-CHON, K.-CHO, Y. (2008): The effects of Korean pop culture on Hong Kong residents' perceptions of Korea as a potential tourist destination Journal of Travel \& Tourism Marketing 24 (2-3): 163-183. https://doi.org/10.1080/10548400802092684

KING, L. M.-HALPENNY, L. A. (2014): Communicating the World Heritage brand: visitor awareness of UNESCO's World Heritage symbol and the implications for sites, stakeholders and sustainable management Journal of Sustainable Tourism 22 (5): 768-786. https://doi.org/10.1080/09669582.2013.864660

Larrington, C. (2016): Winter is Coming: The Medieval World of Game of Thrones Tauris, London.

LARSON, M.-LUNDBERG, C.-LEXHANGEN, M. (2013): Thirsting for vampire tourism: developing pop culture destinations Journal of Destination Marketing and Management 2 (2): 74-84. https:// doi.org/10.1016/j.jdmm.2013.03.004

LI, S.-LI, H.-SONG, H.-LundBERG, C.-SHEN, S. (2017): The economic impact of on-screen tourism: the case of the Lord of the Rings and the Hobbit Tourism Management 60:177-187. https://doi.org/10.1016/j.tourman.2016.11.023

LIN, Y. S.-HUANG, J. Y. (2008): Analyzing the use of TV mini-series for Korea tourism marketing Journal of Travel \& Tourism Marketing 24 (2-3): 223-227. https://doi.org/10.1080/10548400802092858

LundBerg, C.-ZIAKAS, V.-MORGAN, N. (2017): Conceptualising on-screen tourism destination development Tourist Studies (forthcoming) https://doi.org//10.1177/ 1468797617708511

MACIONIS, N. (2004): Understanding the Film-Induced Tourist In: WARWICK, F.-CROY G.Beeton, S. (eds.) International Tourism and Media Conference Proceedings pp. 86-97., 24 ${ }^{\text {th }}-26^{\text {th }}$ November 2004. Tourism Research Unit, Monash University, Melbourne.

MARSHALL, K. (2015): Atlas of a concave world: Game of Thrones and the historical novel Critical Quarterly 57 (1): 61-70. https://doi.org/10.1111/criq.12175

O'CONNOR, N.-FLANAGAN, S.-GILBERT, D. (2008): The integration of film-induced tourism and destination branding in Yorkshire, UK International Journal of Tourism Research 10 (5): 423-437. https://doi.org/10.1002/jtr.676

O'CONNOR, N. (2011): A conceptual examination of the film induced tourism phenomenon in Ireland European Journal of Tourism, Hospitality and Recreation 2 (3): 105125.

PAPP-VÁRY, Á. (2015): Indicators and methodologies for the assessment of product placement Journal of Media Research 8 (2): 27-40.

PAPP-VÁRY, Á.-NOVODONSZKI, G. (2016): Branded entertainment and integrated product placement in Tom Hanks movies Journal of Media Research 9 (3) :3-23.

PuCzKÓ, L.-RÁTZ, T. (2003): Turizmus történelmi városokban. Tervezés és menedzsment Turisztikai Oktató és Kutató Kkt., Budapest

REIJNDERS, S. (2010a): Places of the imagination: an ethnography of the TV detective tour Cultural Geographies 17 (1): 37-52. https://doi.org/10.1177/1474474009349998

Regional Statistics, Vol. 7. No. 2. 2017: 58-74; DOI: 10.15196/RS07201 
"Mind the scenery!" Landscape depiction and the travel intentions of Game of Thrones fans: some in-sights for DMOs

REIJNDERS, S. (2010b): On the trail of 007: Media pilgrimages into the world of James Bond Area 42 (3): 369-377. https://doi.org/10.1111/j.1475-4762.2009.00930.x

RILEY, R.-VAN DOREN, C. (1992): Movies as tourism promotion: a push factor in a pull location Tourism Management 13 (3): 267-274. https://doi.org/10.1016/02615177(92)90098-R

RojeK, C. (1997): Indexing, Dragging and the Social Construction of Tourist Sight In: RoJeK, C.-Urry, J. (eds.) (1997) Tourism Cultures. Transformation of Travel and Theory pp. 52-74., Routledge, USA,

SHANI, A., WANG, Y., HudSON, S., GIL, S.M. (2009): Impacts of a historical film on the destination image of South America. Journal of Vacation Marketing 15 (3): 229-242. https://doi.org/10.1177/1356766709104269

Scharl, A.-Hubmann-Haidvogel, A.-Jonesa, A.-Fischl, D.-Kamolov, R.Weichselbraun, A.-RAFElsBerGER, W. (2016): Analysing the public discourse on works of fiction. Detection and visualisation of emotion in online coverage about HBO's Game of Thrones Information Processing and Management 52 (1): 129-138. https://doi.org/10.1016/j.ipm.2015.02.003

STANTON, R. (2015): Excessive and appropriate gifts: hospitality and violence in A Song of Ice and Fire Critical Quarterly 57 (1): 49-60. https://doi.org/10.1111/criq.12173

TKALEC, M.-ZILIC, I.-RECHER, V. (2017): The effect of film industry on tourism: Game of Thrones and Dubrovnik International Journal of Tourism Research 19 (6): 705714. https://doi.org/10.1002/jtr.2142

TOOKE, N.-BAKER, D. (1996): Seeing is believing: the effect of film on visitor numbers to screened locations Tourism Management 17 (2): 87-94. https://doi.org/ 10.1016/0261-5177(95)00111-5

URRY, J. (1994): Cultural change and contemporary tourism Leisure Studies 13: 233-238. https://doi.org/10.1080/02614369409510672

VOLO, S.-IRIMIÁS, A. (2016): Film tourism and post-release marketing initiatives: a longitudinal case study Journal of Travel and Tourism Marketing 33 (8): 1071-1087. https://doi.org/10.1080/10548408.2015.1094000

\section{WEB REFERENCES}

www.independent.co.uk (2017): Game of Thrones Season 7: more people watch premiere illegally in UK and US than legally. http://www.independent.co.uk/lifestyle/gadgets-and-tech/news/game-of-thrones-season-7-torrents-downloadsstreams-first-episode-illegal-watching-figures-a 7852691.html

Business Insider (2017): This season of 'Game of Thrones' had the most watched premiere in HBO history. http://uk.businessinsider.com/game-of-thrones-season-7premiere-ratings-biggest-in-hbo-history-2017-8?IR=T

Regional Statistics, Vol. 7. No. 2. 2017: 58-74; DOI: 10.15196/RS07201 
APPENDIX

Measurement and reliability of constructs

\begin{tabular}{|c|c|c|c|c|}
\hline $\begin{array}{c}\text { Construct } \\
(\text { Dijkstra-Henseler's } \rho)\end{array}$ & Item & $\begin{array}{l}\text { Standardised } \\
\text { factor } \\
\text { loading }\end{array}$ & Mean & $\begin{array}{l}\text { Standard } \\
\text { deviation }\end{array}$ \\
\hline \multirow{2}{*}{$\begin{array}{r}\text { Resonance of landscape } \\
\text { depiction }(A=0.871)\end{array}$} & Natural landscape depiction & 0.945 & 4.46 & 1.757 \\
\hline & Urban landscape depiction & 0.932 & 4.45 & 1.686 \\
\hline \multirow[t]{3}{*}{$\begin{array}{l}\text { Place attachment } \\
\quad(\rho A=0.784)\end{array}$} & $\begin{array}{l}\text { I am amazed by the landscape in which } \\
\text { GoT is set }\end{array}$ & 0.851 & 3.65 & 1.824 \\
\hline & $\begin{array}{l}\text { I am interested in GoT filming loca- } \\
\text { tions }\end{array}$ & 0.890 & 5.15 & 1.656 \\
\hline & $\begin{array}{l}\text { GoT filming locations are particularly } \\
\text { significant for me }\end{array}$ & 0.783 & 4.97 & 1.738 \\
\hline \multirow{3}{*}{$\begin{array}{l}\text { Information gathering } \\
\text { about locations } \\
(\rho A=0.779)\end{array}$} & $\begin{array}{l}\text { I like checking pictures on GoT filming } \\
\text { locations }\end{array}$ & 0.862 & 3.04 & 1.809 \\
\hline & $\begin{array}{l}\text { I collect information on specific film- } \\
\text { ing locations }\end{array}$ & 0.824 & 1.75 & 1.152 \\
\hline & $\begin{array}{l}\text { I like comparing film locations on } \\
\text { screen and in reality }\end{array}$ & 0.791 & 2.85 & 1.907 \\
\hline \multirow[t]{3}{*}{$\begin{array}{l}\text { Travel intention } \\
\quad(\rho A=0.790)\end{array}$} & $\begin{array}{l}\text { I plan to travel to one of the GoT loca- } \\
\text { tions in the near future }\end{array}$ & 0.859 & 2.65 & 1.803 \\
\hline & $\begin{array}{l}\text { I strongly desire to travel to one of the } \\
\text { GoT locations }\end{array}$ & 0.800 & 2.21 & 1.498 \\
\hline & $\begin{array}{l}\text { I am very likely to travel to one of the } \\
\text { GoT locations in the near future }\end{array}$ & 0.857 & 2.09 & 1.507 \\
\hline
\end{tabular}

Note: Each item was measured on a seven-scale Likert-scale where $1=$ not resonant at all, $7=$ extremely resonant.

Source: Own calculation. 